\section{Greens losing gene battle}

\section{Munich}

OPPONENTS of genetic engineering in West Germany are in retreat following a recent licensing decision and the passage of a long-awaited new law prescribing the conditions under which companies may use genetic-engineering techniques.

Last week, the local government in Cologne approved the construction of a production plant at the company Grünenthal AG in Aachen that will use genetically-engineered bacteria to produce the anti-clotting drug Saruplase.

And in Frankfurt, the passage of the socalled 'gene law' led to a swift retreat of local activists who had appealed to the courts to prevent the operation of a nearly completed pilot plant at Hoechst AG that will produce human insulin from Escherichia coli bacteria.

The recent developments give hope to pharmaceutical producers that West Germany will no longer be a black hole for industrial gene manipulation. Despite the good safety record of industrial genetic engineering in other countries, West German officials have permitted one company only (Boehringer Ingelheim) to use genetically engineered bacteria to produce drugs.

\title{
New programme launched
}

\section{San Franclsco}

IN an attempt to apply interdisciplinary methods to the study of global environmental concerns, a new programme known as the National Institute for Global Environmental Change (NIGEC) was launched this month by the University of California and the US Department of Energy (DOE). NIGEC, which has a \$6 million DOE start-up grant, is a nationwide network of academic research on global environmental issues. The national centre, at the University of California at Davis, will coordinate projects at four regional research centres around the country, in the hope of clarifying the science behind complex problems such as the greenhouse effect, ozone depletion, and general issues of energy use and pollution.

NIGEC will not address policy issues, but scientists see the DOE funding as a sign of increasing government interest in environmental issues. US researchers tend to believe that Western European countries and Japan are the nations "on the cutting edge of making enlightened recommendations" on how to deal with global environmental changes, according to Joseph Knox, acting director of the NIGEC. But he is encouraged by recent US efforts. "The government has been talking about being interested in this area for a long time. It's gratifying to see some actual progress," said F. Sherwood Rowland, a co-director of NIGEC and a professor of chemistry at the University of California, Irvine.

Although some universities have had environmental programmes running for several years, researchers say that the past year has brought an increase in the number of groups studying environmental change on a planetary scale, as well as a tendency to combine a broad mixture of disciplines.

Stanford University in California, for example, is developing a new undergraduate course, aimed at understanding the Earth as an interactive system; it will mix studies in Earth sciences, biological sciences, economics, policy analysis and environmental engineering. Some classes for the programme, called Earth Systems, are thought likely to begin during the next academic year.

Administrators report bureaucratic obstacles to the creation of programmes that require co-ordination between several academic departments or between different institutions, but Alan Miller, director of the year-old Center for Global Change at the University of Maryland, predicts that increasing demand will push many more universities into beginning such studies with a global theme.

The NIGEC will combine basic scientific research in biological, Earth and atmospheric sciences with studies of such issues as energy policies and fuel consumption. The regional centres, located at Harvard University, Indiana University, Tulane University in New Orleans and the University of California, are designed to foster interdisciplinary research within and among universities located in different parts of the country. As well as attacking global issues, each center will concentrate some of its efforts on understanding the causes and effects of environmental change in its particular geographic and climatic region, said Knox.

Harvard's studies, for example, will include a focus on temperate forests, while the University of California centre will include atmospheric chemistry at Irvine and studies of water resources, agriculture and ecosystems at Davis. At present 60 to 70 research programmes are participating, and the NIGEC will solicit additional proposals later this year.

Elizabeth Schaefer
Both companies can rely on a pivotal clause in the new law to protect them from further appeals. The clause states that public hearings will not be required for the licensing of production facilities that rely on genetically manipulated bacteria in the lowest of four risk classes. Both the Grünenthal and Hoechst plants rely on a bacterium in this category, a 'safety strain' of $E$. coli known as K-12.

The positive decision in the Grünenthal case came after a public hearing last autumn, which was required by the old law governing genetic engineering, the Federal Emission Protection Act. The Cologne head of government, FranzJosef Antwerpes, used the new gene law as a standard to measure the application. $\mathrm{He}$ declared that Grünenthal would go even further than the law requires to protect the local population and its own employees from potential hazards.

Unless there is another appeal, which now seems unlikely, Grünenthal expects to complete construction of its Aachen plant in 1992.

Hoechst had nearly completed its $\$ 60$ million pilot plant in 1987 , when it was granted a licence to produce human insulin there. But the licence was held up in the courts until this year by the Hoechster Schnüffler und Maagucker, a local opposition group.

Last November, a court ruled that the plant could not be used until there was a legal basis for regulating the use of genetic engineering (see Nature 342, 218; 1989). After passage of the new law, opponents declared the suit null and void. Once Hoechst has received official approval from the court, it will complete the pilot plant and apply early next year to build a full-scale insulin plant in Frankfurt.

In cases where other organisms are used to produce drugs, the outcome may not be so clear-cut. Another company, Behringwerke $A G$ of Marburg, is waiting with bated breath for its local government to decide if it may use mouse cells in culture to produce the anti-anaemia medication erythropoietin, also known as EPO. Spokesman Wolfgang Faust said a ruling is expected in September.

Although they are not happy about the recent turn of events, opponents of genetic engineering, such as Green Party parliamentarian Katrin Grüber in North Rhine-Westphalia (where Grünenthal is located) are not ready to admit defeat. "We don't believe that the public ever had a chance to say if it wants medications produced by these methods. We will continue our work by doing public relations and distributing flyers, so that patients will at least know what they are taking." But Grüber admits that it will be impossible to overturn or revise the genetic engineering law without the support of a larger party than the Greens. And that seems unlikely.

Steven Dickman 